УДК: 368

JEL classification: $G 22$, C6

Диба В.А.

ORCID ID: 0000-0001-7653-1295

Національний технічний університет Украӥни

«Київський політехнічний інститут імені Ігоря Сікорського»

\title{
ВИКОРИСТАННЯ СТОХАСТИЧНОГО МОДЕЛЮВАННЯ ДЛЯ ЗАБЕЗПЕЧЕННЯ СТАБІЛЬНОГО РОЗВИТКУ СТРАХОВИХ КОМПАНІЙ ЗАОЩАДЛИВОГО ТИПУ НА РИНКУ УКРАЇНИ
}

\author{
ИСПОЛЬЗОВАНИЕ СТОХАСТИЧЕКОГО МОДЕЛИРОВАНИЯ ДЛЯ \\ ОБЕЗПЕЧЕНИЯ СТАБИЛЬНОГО РАЗВИТИЯ СТРАХОВЫХ КОМПАНИЙ \\ СБЕРЕГАТЕЛЬНОГО ТИПА НА РЫНКЕ УКРАИНЫ
}

\section{USING THE STOCHASTIC MODELING FOR ENSURING STABLE DEVELOPMENT OF THE INSURANCE COMPANIES SAVING TYPE IN THE UKRAINIAN MARKET}

У ціий статті проведено аналіз сучасного стану страхового ринку Украйни, зокрема діяльності страхових компаній ощадливого типу. Розглянуто механізм функціонування страхових компаній накопичуваного типу, їх інвестиційної діяльності та процеси взаємодії з клієнтами. Проведено аналіз змін, які відбулися у продовж 2015-2016 років на ринку страхування України. Для підвищення ефективності прочесу прийняття рішень про наявність засобів, які мають виділятися серед потениійних інвестицій, була розроблена багатоступінчаста стохастична модель ефективного управління активами та пасивами страхової компанії ощадливого типу, яка дозволяе керівництву компанї компаніям ефективно управляти інвестиційною діяльністю з урахуванням поточних та майбутніх зобов'язань по страховим полюсам для мінімізачії ризиків та для покращення майбутнього добробуту компанії. Загальна ціль моделювання полягає у тому, щюб максимізувати очікуваний чистий прибуток за кожний плановий період за вирахуванням страхових виплат. Багатоступінчаста стохастична модель оптимального управління активами та пасивами страхової компанї дозволяе знаходити оптимальний розподіл отриманого інвестииійного прибутку та очікуваний баланс для кожного для кожного модельованого періоду, розподіл ймовірностей дефіиитів страхового резерву, а також стан кожного регулюючого обмеження для кожного типу активів компанії.

Ключові слова: страхування, страховий ринок, моделювання, стохастичне програмування, інвестування, страхування в Україні.

В статье проведен анализ современного состояния страхового рынка Украины, в частности деятельности страховых компаний сберегательного типа. Рассмотрен механизм функиионирования страховых компаний накопительного типа, их инвестиционная деятельность и прочессы взаимодействия с клиентами. Проведен анализ изменений, которые произошли на протяжении 2015-2016 годов на ринке страхования Украины. Для повышения эффективности прочесса принятия решений про наличие средств, которые должны выделяться среди потенциальных инвестиций, была разработана многоступенчатая стохастическая модель эффективного управления активами и пассивами страховой компании накопительного типа, которая позволяет 
руководству компании эффективно управлять инвестиционной деятельностью с учетом текущих и будущих обязательств по страховым полюсам для минимизации рисков $и$ улучшения будущего благосостояния компании. Общая иель моделирования состоит максимизации ожидаемого чистого дохода за каждый плановый период с вычетом страховых выплат. Многоступенчатая стохастическая модель оптимального управления активами и пассивами страховой компании помогает находит оптимальное распределение полученной инвестищионной прибыли и ожидаемый баланс для каждого планового периода, распределение вероятностей дефицита страхового резерва, так же состояние каждого регулирующего ограничения для каждого типа активов компании.

Ключевые слова: страхование, страховой рынок, моделирование, стохастическое программирование, инвестирование, страхование в Украине.

In this article I analysed the current state of the insurance market of Ukraine, in particular the activities of saving type insurance companies. I considered the mechanism of functioning of insurance companies saving type, its investment activities and the processes of interaction with customers. Also there was made an analysis of the changes that have taken place over the 20152016 years at the insurance market in Ukraine. To improve the efficiency of decision about the existence of making money that should be allocated among the potential investment has been developed multistage stochastic model of efficient management of assets and liabilities of the insurance company the storage type, which allows the management company to manage the investment activities effectively, taking into account current and future obligations under the insurance policy for the minimize risks and improve the company's future prosperity. The overall objective of the simulation is to maximize expected long-run profits less expected penalty cost from constraint violations over the panning horizon. Multistage stochastic model of optimal management of assets and liabilities of the insurance company helps to find the optimal distribution of the resulting profits investment and expected balance for each planning period, the probability distribution of the insurance reserve deficit, as the status of each of the regulatory limits for each type of asset.

Keywords: insurance, insurance market, modelling, stochastic programming, investment, insurance in Ukraine.

Вступ. Розвиток страхового ринку України, концентрація значних фінансових ресурсів у страховиків призводить до того, що страхові компанії $\epsilon$ великими інвесторами на фінансовому ринку. Побудова оптимального інвестиційного портфеля, ефективне управління інвестиційною діяльністю - ці питання є актуальними для всіх страхових компаній України. Кожна страхова компанія прагне до підвищення своєї фінансової стійкості, платоспроможності та конкурентоспроможності. Зацікавленість страховиків в оптимальному управлінні інвестиційною діяльністю заснована на наступних положеннях. По-перше, інвестиційна діяльність визначає саму можливість надання страхових послуг за рахунок забезпечення формування достатнього грошового фонду для виконання страхових зобов'язань (насамперед це стосується страхування життя, оскільки планована прибутковість від інвестицій враховується при розрахунку тарифів). По-друге, успішна інвестиційна діяльність впливає на конкурентоспроможність страхового 
продукту на ринку; по-третє, інвестування дає можливість власникам страхової компанії розвивати свій бізнес.

Для інвестування страхова компанія може використовувати кошти, пов'язані 3 виконанням страхових зобов'язань, i власний капітал. Власний капітал є відносно вільними від страхових зобов'язань грошовими коштами. Розглянемо грошові кошти, пов'язані з виконанням страхових зобов'язань. Відповідно до чинних «Правил формування, обліку та розміщення страхових резервів» [1] під розміщенням страхових резервів розуміються активи, що приймаються в покриття (забезпечення) страхових резервів. Активи, що приймаються в покриття страхових резервів, повинні відповідати умовам диверсифікації, повернення, прибутковості і ліквідності, входити в дозволений список активів і задовольняти тим вимогам, які пред'являються до кожного з видів активів.

Під динамічним балансом страхової компанії будемо розуміти сукупність активів, прийнятих у покриття страхових резервів, i пасивів (страхових резервів), при цьому величина активів коригується і враховується можливість перебудови інвестиційного портфеля з плином часу в залежності від наступних факторів: транзакційних витрат, законодавчого регулювання, отриманого інвестиційного доходу, відповідності величиною страхових резервів.

Проблеми розвитку та побудови страхового ринку i діяльності страхових компаній зокрема знайшли своє відображення у багатьох роботах вітчизняних і зарубіжних наукових діячів, таких як О. Вовчак, І. Кривцун, В. Плиса, Н. Добош, В. Базилевич, Н. Внукова, І. Балабанов, О. Билак, Н. Ковтун, О. Козьменко, В. Заруба, С. Юрій, які глибоко досліджували питання ефективного функціонування страхового ринку України, зокрема фінансовий стан вітчизняних страхових компаній.

Так, В. Плиса розглядає страховий ринок як особливу соціальноекономічну структуру, якусь сферу грошових відносин, де об'єктом купівліпродажу є страховий захист, формуються пропозиція і попит на нього. Також він вивчав стратегії інтеграції страхового ринку України в світовий страховий простір.

В. Алексєєнко розглядає діяльність страхових компаній в умовах трансформації ринкових процесів, Д. Тупчієнко описує роль страхових компаній в інвестиційний процесах країни, С. Нестерова аналізує ринок страхових послуг України в цілому. Також значна увага функціонування страхових організацій в нашій країні приділяють Н. Шурігіна, О. Жабінець, А. Василенко, В. Тринчук, В. Баранова та інші наукові діячі. 
Постановка завдання. Ціль роботи полягає у тому, щоб покращити процес прийняття рішень для страхової компанії про іiі інвестиційні та платіжні обов'язки для загального управління ризиками із урахуванням існуючих та майбутніх зобов'язань по страховим полюсам накопичуваного типу.

Методологія. Під час написання статті були використанні такі методи дослідження як аналіз, порівняння, спостереження та узагальнення та системний підхід. Також в роботі використаний графічний метод представлення даних.

Результати дослідження. Проблеми діяльності страхових компаній в Україні залишаються не вирішинними і потребують особливої уваги не лише 3 теоретично, але й практично.

Діяльність страхових компаній є досить специфічною, адже замість класичного товару, на ринку такі компаній пропонують особливий товар страховий захист, за який отримує певну плату. Але нажаль, серед населення нашої країни не розвинута страхова культура та є значна ступінь недовіри до страхових компаній, через нечесну діяльність останніх.

Страхові компанії заощаджуваного типу - це специфічний вид страхових компаній, які спеціалізуються на страхуванні життя та на створенні страхових накопичених полюсів. Страхова компанія видає своїм клієнтам страховий поліс на певний строк (як правило від 5-10 років), за яким окрім забезпечення захисту життя або від нещасного випадку, також виплачується відшкодування по закінченню зазначеного в полісі періоду. Відшкодування складається з частини страхових премій плюс відсотки по ставці, яку гарантує поліс. На кожного клієнта страхова компанія відкриває окремий ощадний рахунок, куди наприкінці звітного року нараховує бонуси. Страхові компанії конкурують за ці бонуси. В Україні досить високі відсоткові ставки по бонусам, порівняно з європейськими країнами.

Звичайно, що бонуси страхові компанії можуть виплачувати із отриманого інвестиційного доходу. Згідно страхового законодавства, джерелом інвестицій можуть виступати власні кошти страхової компанії (статутний капітал, наприклад) і залучені кошти (страхові премії та кошти на ощадних полюсах). Проте в Україні досить обмежені можливості для інвестування. Адже страхові компанії не можуть дозволити собі інвестувати у проекти із високими ризиками.

За 2016 рік в порівнянні із попередніми роками страховики значно скоротили обсяг інвестицій в цінні папери з обмеженою ліквідністю, а частка фінансових інвестицій в структурі активів, якими можуть бути представлені страхові резерви, усього за рік скоротилася майже на 15 п.п. При цьому, обсяг 
балансових активів страховиків 3 початку 2015 року зменшився на 23,8\% - до 53,5 млрд. грн. станом на 01.04.2016 р. (балансова вартість активів страхових компаній, що здійснюють страхування життя - 10,70 млрд. грн.), а обсяг активів, якими можуть бути представлені страхові резерви відповідно до чинного законодавства (тут і далі - ліквідні активи ) - на 16,2\% (до 33,95 млрд. грн. станом на 01.04.2016 p). Основний обсяг ліквідних активів представлений засобами на депозитних (12,14 млрд. грн.) та поточних (2,80 млрд. грн.) рахунках в банківських установах. Близько $20 \%$ - в сукупності склали права вимоги до перестрахувальників (3,71 млрд. грн.) I інвестиції в ОВДВ3 (3,48 млрд. грн). При цьому, частина активів страховиків все ще представлена інвестиціями в акції, що в умовах низької ліквідності фондового ринку України, залишається джерелом потенційного ризику для страхового сектора. У той же час, ревізія якості інвестиційних активів (в тому числі, через ліквідацію окремих банків, низьку ліквідність фондового ринку і ринку нерухомості) привела до істотного коректування фінансового результату окремих страховиків.

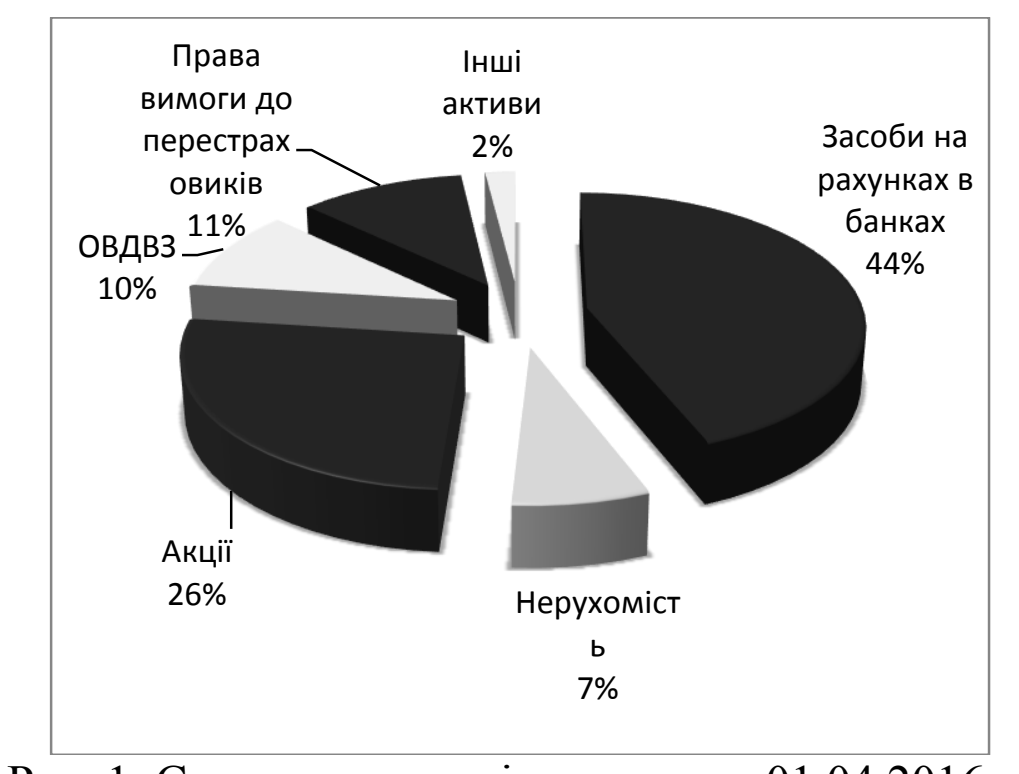

Рис. 1. Структура активів станом на 01.04.2016 p.

Згідно звіту Національної комісії, зо здійснює державне регулювання у сфері ринків фінансових послуг про стан страхового ринку України, на кінець першого півріччя 2016 року в країні нараховувалося 343 страхові компанії. 3 початку року зі страхового ринку пішло з різний причин 18 компаній. Загалом 3 початку 2015 року з ринку пішло 39 компаній (таблиця) [5]. 
Кількість страховий компаній в Україні

\begin{tabular}{|c|c|c|c|c|}
\hline Кількість страховий компаній & $\begin{array}{c}\text { Станом } \\
\text { на } \\
\mathbf{3 1 . 1 2 . 2 0 1 4}\end{array}$ & $\begin{array}{c}\text { Станом } \\
\text { на } \\
\mathbf{3 1 . 1 2 . 2 0 1 5}\end{array}$ & $\begin{array}{c}\text { Станом } \\
\text { на } \\
\mathbf{3 0 . 0 6 . 2 0 1 5}\end{array}$ & $\begin{array}{c}\text { Станом } \\
\text { на } \\
\mathbf{3 0 . 0 6 . 2 0 1 6}\end{array}$ \\
\hline Загальна кількість & 382 & 361 & 374 & 343 \\
\hline В т.ч. СК «Life» & 57 & 49 & 52 & 45 \\
\hline
\end{tabular}

Якщо розглядати діяльність страхових компаній більш детально, то головними бізнес-цілями страхових компаній накопичуваного типу є наведене на рис. 2:

$$
\begin{aligned}
& \text { Максимізація очікуваного благополучча страхової } \\
& \text { компанії в довгостроковій перспективі; }
\end{aligned}
$$

Виплати достятньо великих відсотків за по страховим полюсам, щоб залишатися конкурентноспроможними зі сторони дохідності та майбутніх запасів;

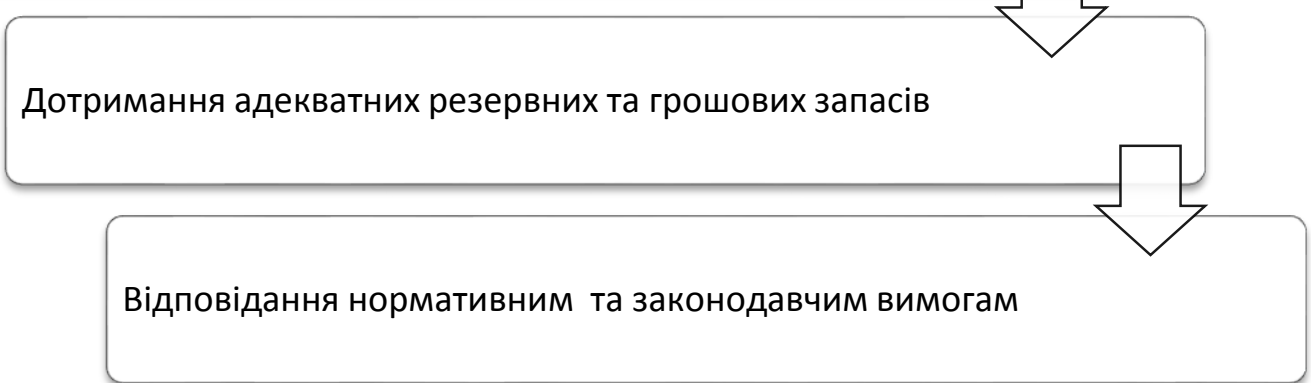

Рис. 2. Головні бізнес-цілі страхових компаній накопичуваного типу

В своїй діяльності кожна страхова компанія стикається із проблемою пов'язаною із зростанням кількості проданих полюсів, які в свою чергу створюють нові види зобов'язань. Ще однією проблемою $\epsilon$ регулюючі нормативи держави, які накладають безліч обмежень за допомогою страхового права, яке призводить к складним обмеженням.

Зобов'язання страхових компаній являються багатоперіодними за своїм характером. Кожного дня існує графік обіцяних виплат клієнтам, які тримають страхові поліси, та іншим кредиторам на протязі довгого часу.

Такі зобов'язання описуються у літературі як залишки відповідальності. Ці залишки змінюються на плином часу, коли здійснюються заплановані платежі, оскільки страхові резерви включають як існуючі зобов'язання, так і нові. Отже має існувати багатоперіодних характер для прийняття рішень про розподіл засобів. 
Хоча розподіл активів відбувається сьогодні, подібні рішення мають прийматися, в принципі, при будь-якій можливості в майбутньому. Приймаючи за увагу влив кожного прийнятого рішення про розподіл майбутнього багатства, при управлінні активами та зобов'язаннями, страхова компанія має використовувати багатоперіодну модель прийняття рішень.

Інший фундаментальний аспект проблеми управління активами та пасивам страхової компанії $є$ випадковий характер майбутньої дохідності активів. Адже інвестиційна діяльність страхової компанії є ризиковою: якщо прибутковість інвестиційних проектів буде занизькою, компанія не зможе покрити зобов'язання за полюсами.

Формулювання моделі. Для підвищення ефективності процесу прийняття рішень про наявність засобів, які мають виділятися серед потенційних інвестицій, була розроблена модель для забезпечення дохідності страхової компанії для покриття зобов'язань по виплатам та забезпечення довгострокового росту добробуту фірми. Загальна ціль моделювання полягає у тому, щоб максимізувати очікуваний чистий прибуток за перший період за вирахуванням страхових виплат:

Мах Е [Загальна ринкова вартість - сума накопичених зобов'язань ]

Де Загальна ринкова вартість є сумою всіх отриманих страхових платежів, а сума накопичених зобов'язань включає в себе вартість накопичених зобов'язань та вартість зобов'язань на кінець періоду.

Основною одиницею виміру в моделі $\epsilon$ календарний квартал $t=$ $0,1, \ldots, T$. Оскільки модель враховує особливості бухгалтерського обліку діяльності страхової діяльності в Україні. Періоди мають різну довжину:

- 8 відгалужень у першому періоді (перший квартал);

- 4 відгалуження у другому періоді (для першого року);

- 4 відгалуження у третьому періоді (для другого року);

- 2 відгалуження у четвертому періоді (3-5 рік);

- 1 відгалуження у шостому періоді (термінальні умови).

Таким чином, загальна кількість сценаріїв у моделі: $8 \times 4 \times 4 \times 2 \times 1=$ 256 (рис. 3). 


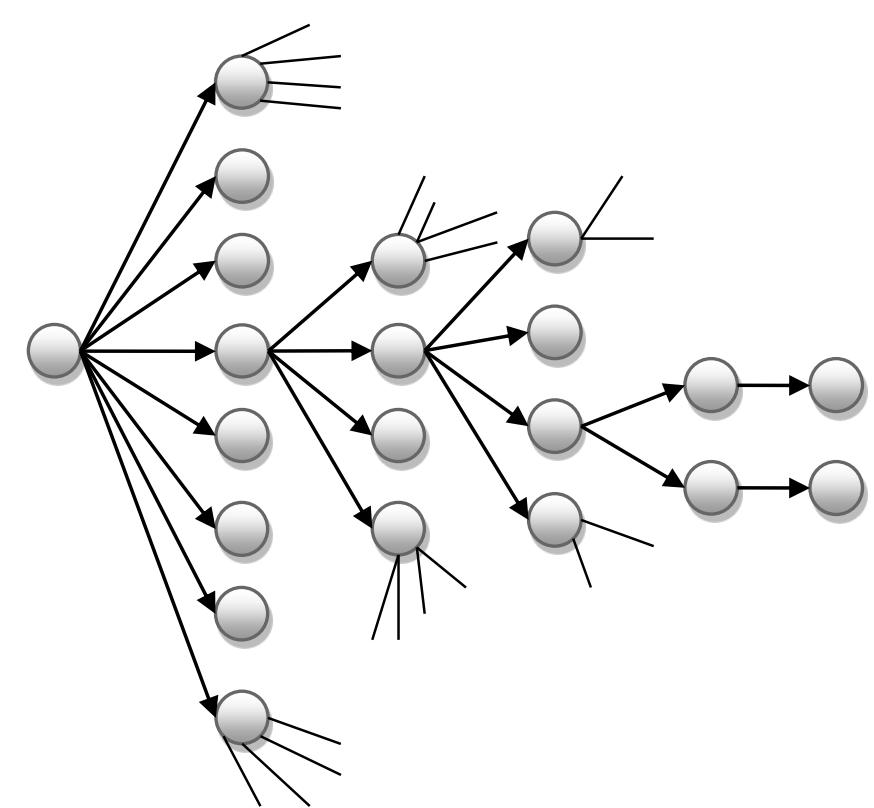

Рис. 3. Кількість сценаріїв у моделі

Керовані змінні моделі:

$V_{t}$ - загальна ринкова вартість, для якої виконується рівність,

$X_{n t}$ - ринкова вартість накопичених активів $n$ за плановий період $\mathrm{t}$,

$w_{t+1}$ - дефіцит доходів в період $\mathrm{t}+1$,

$v_{t+1}-$ профіцит доходів в період $\mathrm{t}+1$.

Випадкові змінні

$R P_{n t+1}$ - вартість повернення активів $\mathrm{n}$ з кінця періоду $\mathrm{t}$ до початку $\mathrm{t}+1$,

$P I_{n t+1}$ - дохід від повернення активів $\mathrm{n}$ з кінця періоду $\mathrm{t}$ до початку $\mathrm{t}+1$,

$F_{t+1}$ - надходження вкладів з кінця періоду $\mathrm{t}$ до початку $\mathrm{t}+1$,

$P_{t+1}-$ основні виплати з кінця періоду $\mathrm{t}$ до початку $\mathrm{t}+1$,

$I_{t+1}$ - виплати за відсотками з кінця періоду $\mathrm{t}$ до початку $\mathrm{t}+1$,

$g_{t+1}$ - швидкість зарахування відсотків на поліси з кінця періоду $\mathrm{t}$ до початку $\mathrm{t}+1$,

$L_{t}$ - оцінка зобов'язань.

Ціллю моделі $\epsilon$

Таким чином модель має вигляд:

$$
\operatorname{Max} E\left[V_{T}-\sum_{t=1}^{T} c_{t}\left(w_{t}\right)\right]
$$

де

$\sum_{t=1}^{T} c_{t}\left(w_{t}\right)$ - вартість накопичених зобов'язань на плановий період $\mathrm{t}$.

При чому параметрізована функція $c_{t}(\cdot)$ - кусково-лінійна випукла функція витрат (рис. 4) 


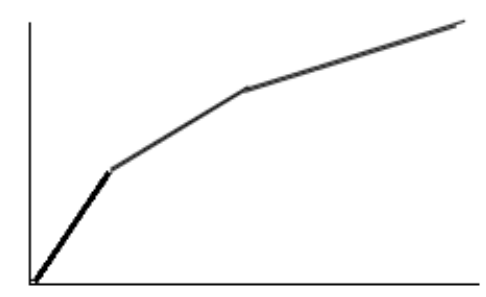

Рис. 4. Випукла параметрізована функція затрат

Модель має бюджетні обмеження:

$$
V_{t}=\sum_{n} X_{n t}
$$

Взаємозв'язок накопичених актів можна розрахувати із наступної нерівності:

$$
V_{t+1}-\sum_{n}\left(1+R P_{n t+1}+R I_{n t+1}\right) X_{n t}=F_{t+1}-P_{t+1}-I_{t+1}
$$

Обмеження для накопиченої суми зобов'язань по полісам:

$$
\begin{aligned}
& \sum_{n} R I_{n t+1} X_{n t}+w_{t+1}-v_{t+1}=g_{t+1} L_{t} \\
& \quad x_{n t} \geq 0, v_{t+1} \geq 0, w_{t+1} \geq 0 \text { для всіх } t=[0, T-1]
\end{aligned}
$$

Вартість накопичених зобов'язань можна також виразити як суму вартості накопичених зобов'язань та вартість зобов'язань за кінцевий період. Вартість накопичених зобов'язань можемо виразити наступним чином:

$$
\sum_{i} \sum_{t=1}^{T}(1+\gamma)^{N(t, T)} \mathrm{C}_{i t} S_{i t}
$$

де $N(t, T)$ - кількість років від шагу $t$ до майбутнього періоду $T$, $\gamma$ - річна відсоткова ставка,

$C_{i t}$ - економічна ефективність для зобов'язань $i$ на стадії $t$, $S_{i t}$ - сума зобов'язань $i$ на стадії $t$.

Вартість зобов'язань за кінцевий період виражаємо як:

$$
\sum_{i} \alpha C_{i f} S_{i f}
$$

Де $\alpha-$ коефіцієнт дисконтування за кінцевий період,

$C_{i f}-$ коефіцієнт витрат по зобов'язанням $i$ за кінцевий період $f$,

$S_{i f}$ - сума зобов'язань типу $i$ за кінцевий період $f$.

Таким чином, ми отримали модель управляння активами та пасивами страхової компанії із використанням багатоступінчастого стохастичного програмування. Вона визначає оптимальну інвестиційну стратегію, яка 
включає багатоперіодний підхід і дозволяє особам, які приймають рішення, визначити матеріальні ризики в оперативному плані. Найголовніша задача моделі полягає у поверненні високого доходу по річними виплатам за страховими полюсами клієнтам, без завдання шкоди для цілі максимізації довгострокового благополуччя страхової компанії.

Висновки. Наукова новизна статті полягає у запропонованій багатоступінчастої стохастичної моделі ефективного управління активами та пасивами страхової компанії ощадливого типу, яка дозволяє керівництву компанії компаніям ефективно управляти інвестиційною діяльністю при розміщенні страхових резервів із страхування життя. Дана модель дозволяє визначити оптимальну інвестиційну стратегію, враховуючі суму зобов'язань по полюсам страхової компанії у кожний конкретний момент часу. Таким чином, головною ціллю моделі є забезпечення та максимізація благополуччя та стабільності страхової компанії у довгостроковій перспективі, із урахування максимально можливих виплат по полюсам, для забезпечення конкурентоспроможності компанії на ринку.

Багатоступінчаста стохастична модель оптимального управління активами та пасивами страхової компанії має ряд переваг: дозволяє знаходити оптимальний розподіл отриманої інвестиційного прибутку для кожного періоду, очікуваний баланс для кожного періоду, розподіл ймовірностей дефіцитів, а також стан кожного регулюючого обмеження низки активів.

Надалі планується практичне використання даної моделі для управління невеликою страховою компанією.

\section{Література:}

1. Беспалова А.Г. Развитие страхового рынка Украины в условиях экономического кризиса / А.Г. Беспалова, Н.В. Югас // Финансы, учет, банки. - 2009. - №1(15). - с.7277.

2. Внукова Н.М. Страхование: теория и практика : [учебное пособие] / Н.М. Внукова, Л.В. Временко, В.І. Успаленко. - 2 изд., переделанное та дополненное.- Харьков : Бурун Книга, 2009. -655 c.

3. Гавриляк Т.С. Влияние мирового финансового кризиса на страховой рынок Украины / Т.С. Гавриляк // Миколіївський національний університет ім. В.О. Сухомлинського. 2014. - №2. - C. 1034-1037.

4. Гребенщиков Э.С. Финансовый кризис в мире: последствия и уроки для страхового бизнеса, регуляторов и страхователей / Э.С. Гребенщиков // Финансы. - 2009. - № 3. C. 53-58.

5. Гуржій С. Г. Боротьба з відмиванням коштів: правовий, організаційний та практичний аспекти / С. Г. Гуржій, О. Л. Копиленко, Я. В. Янушевич та ін. - К. : Парлам. вид-во. 2005. $-216 \mathrm{c}$.

6. Дмитров С. О. Моделювання оцінки ризиків використання послуг банків з метою легалізації кримінальних доходів або фінансування тероризму / С. О. Дмитров, О. В. Меренкова, Л. Г. Левченко // Вісник Національного банку України. - 2009. - № 1. - С. $54-59$. 
7. Офіційний сайт Державної комісії по регулюванню ринку фінансових послуг [Електронний ресурс]. - Режим доступу : http://dgf.gov.ua

8. Пікус Р. Фінансова стійкість страхової організації та джерела ії забезпечення / Р.Пікус, М. Балицька // ВІСНИК Київського національного університету імені Тараса Шевченка. - 2016. - №3(180). - С. 6-9.

9. Статистика страхового ринку України [Електронний ресурс]. - Режим доступу : http://forinsurer.com/stat

10. Тринчук В. Вступ України до СОТ як етап формування страхового ринку відкритого типу / В. Тринчук, С. Дідус // Матеріали II міжнар. наук.-практ. конф. «Проблеми європейської інтеграції і транскордонного співробітництва». - Луцьк: Вежа. — 2005. C. 237-241.

11. Cariño D. R. Concepts, technical issues, and uses of the Russell-Yasuda Kasai financial planning model/ D. R. Cariño, D. H. Myers,// Operations Researc. - 1998. - №46(4). C. $450-462$.

12. Cariño D. R. Formulation of the Russell-Yasuda Kasai financial planning model/ D. R. Cariño, W. T.Ziemba// Operations Research. - 1998. - №46(4). - C. 433-449. 